\title{
The Role of Serum Angiopoietin-Like Protein 4 (ANGPTL-4) and its Gene in Iraq Patients with Type2 Diabetes Mellitus: Case-Control Study
}

\author{
Aseel Ali Abd Ali Sahib*, Mohammed I. Hamzah and Mahmood Shakir Khudhair
}

Chemistry and Biochemistry Department, College of Medicine, Al- Nahrain University, Baghdad-Iraq

\begin{tabular}{l} 
Article's Information \\
\hline Received: \\
12.09.2021 \\
Accepted: \\
19.10.2021 \\
Published: \\
31-12-2021 \\
\hline
\end{tabular}

\section{Keywords:}

Type 2 diabetes mellitus

Angiopoietin-like protein 4

Fasting blood sugar

Glycated hemoglobin

Body mass index

Lipid profile

ANGPTL4 gene

\begin{abstract}
Background
Type 2 Diabetes Mellitus is produced by cell failure of pancreatic cells and insulin resistance and is a disorder in which the amount of sugar in the blood is elevated. Angiopoietin-like protein 4 (ANGPTL4) functions as an inhibitor of lipoprotein lipase, a critical enzyme in lipid metabolism. The aim of this study was to explore if the ANGPTL4 gene's E40K variant and ANGPTL4 serum levels are related to the Body mass index, fasting glucose levels, lipid levels, and glycated hemoglobin.

Method
\end{abstract}

75 people were enrolled in this case-control study, 25 of whom had type 2 diabetes mellitus while the other 50 were healthy control subjects. Fasting blood glucose, Lipid profile, Glycated hemoglobin were estimated by Cobas 111 analyzer, BMI (weight, height) was calculated, angiopoietin-like protein 4 by an enzyme-linked immune sorbent test kit and TaqMan genotyping-based real-time PCR was used to ascertain ANGPTL4 genotypes. The variant was linked to the risk of Type 2 Diabetes Mellitus and parameters used to quantify the variant were identified.

Result

Patients in the 30-50 age range with type 2 diabetes and those in the same age group who serve as controls. The control group had a lower level of angiopoietinlike protein 4 (ANGPTL4) than the diabetes group. Patients with T2DM had a substantially $(\mathrm{p}<0.0001)$ greater fasting serum Angiopoietin-like protein 4 level than the control group $(135.1 \pm 6.70) \mathrm{ng} / \mathrm{ml}$ and $(62.35 \pm 6.4) \mathrm{ng} / \mathrm{ml}$, respectively. The diabetes group has significantly higher fasting serum glucose, lipid profile, and glycated hemoglobin compared with non-diabetics. Serum Angiopoietin-like protein 4 was correlated positively with body mass index. (CC,CT,TT) genotypes of the rs2010871 polymorphism There was a significant difference in frequency of the control group $(\mathrm{p}=0.0477)$; however, there was no significant difference in its level of (diabetics, newly diagnosed type 2 diabetic before treatment) $\mathrm{p}$-value $(0.7066,0.5555)$ respectively

Conclusion

Serum Angiopoietin-like protein 4 levels are negatively correlated to cholesterol, positively correlated to triglyceride, negatively correlated to HDL, positively correlated to $\mathrm{HbA1c}$, negatively correlated to $\mathrm{LDL}$, negatively correlated to VLDL, negatively correlated to FBS, negatively correlated to BMI. The C>T allele at the ANGPTL4 gene's rs2010871polymorphic locus was linked to a decreased prevalence of Type 2 diabetes.

DOI: 10.22401/ANJS.24.4.02

*Corresponding author: aseeltot2015@gmail.com

\section{Introduction}

Diabetes is a long-term condition caused by excessive blood glucose levels (hyperglycemia). The reason is that the body cannot produce insulin (a hormone produced by the pancreas which can control blood sugar levels) or the body cannot be effectively use insulin or both (AIH et al., 2020). There are two main types of diabetes: Type 1 diabetes that develops due to destruction of autoimmune $\beta$-cell, and types
2 diabetes that develops due to the gradual loss of $\beta$-cell on Background of insulin resistance (ADA et al., 2018).Classification of diabetes the malfunction or death of irreplaceable pancreatic cells is the common cause of all types of diabetes. Genetic predisposition, epigenetic processes, Insulin resistance, inflammation, autoimmune, concomitant diseases, and environmental variables are all factors that contribute to the death or weakening of cells 


\section{Al-Nahrain Journal of Science}

ANJS, Vol.24 (4), December, 2021, pp. 7-14

(Rutter GA et al., 2015). According to etiology, however, other forms of diabetes may be associated with a single gene defect. These other forms share features of T1DM and/or T2DM (IDF et al., 2019). Diabetes is divided into the following major groups:

1. Type 1 diabetes mellitus:

Insulin deficiency is caused by the death of autoimmune cells.

2. Type 2 diabetes mellitus:

Insulin resistance causes a gradual decrease in $\beta$-cell insulin secretion.

3. Gestational DM (GDM):

Diabetes that was not overt before pregnancy and was diagnosed in the second or third trimester of pregnancy.

\section{Angiopoietin- Like Proteins (ANGPTLs) and Angiopoietin- Like Proteins 4 (ANGPTL4)}

Angiopoietin-like proteins (ANGPTLs) have attracted a lot of interest as possible pharmacological therapies for insulin resistance and type 2 diabetes. BSJ Davies and colleagues (Davies et al., 2018) (AWF Janssen et al., 2018). Angiopoietin-like proteins (ANGPTLs) are secreted proteins that are structurally similar to angiopoietins; among these, ANGPTL three, four, and eight play a key role in lipid metabolism by binding to and reducing the action of circulating lipoprotein lipase (LPL) (Dijk et al., 2016) (Kersten, M., et al., 2019). Angiopoietin-like proteins kept LPL-mediated lipolysis of triglyceride-rich lipoproteins (TRLs) active in the bloodstream (ANGPTLs). LPL, on the other hand, becomes resistant to ANGPTL-mediated suppression when it binds to GPIHBP1 (glycosylphosphatidylinositol-anchored high-density lipoprotein (HDL)-binding protein 1) is an endothelial membrane protein (Sonnenburg et al., 2009). The overall consequence of ANGPTL-mediated selective LPL inhibition, which occurs in the essential organs including the heart, muscle, and fat, is the process of free fatty acid (FFA) unloading, which provides energy for active metabolism. Genetic study has revealed that genetic variations influencing ANGPTL3 and ANGPTL4 function cause individuals to have reduced triglyceride levels (Romeo et al., 2007) (Bailetti and colleagues, 2018). The inactivating mutation $\mathrm{E} 40 \mathrm{~K}$ of the ANGPTL4 gene has been related to a reduced risk of type 2 diabetes (T2D) in addition to protecting against dyslipidemia (Gusarova et al., 2018). In addition to treatment with monoclonal antibodies targeting ANGPTL3 and ANGPTL4, LPL is triggered by a short-term intervention (Gusarova et al., 2018); early clinical studies indicate that treatment with ANGPTL3 and ANGPTL4 antagonists may improve lipid profiles and reduce cardiovascular risk (Ruscica et al., 2020). Furthermore, ANGPTL4 has been linked to both advanced and impaired glucose tolerance in mice in one-of-a-kind studies (Mandard et al., 2004) (Wang et al., 2016) despite the fact that results on this subject aren't definitive. In contrast, the deletion of ANGPTL4 in mice has improved insulin sensitivity and glucose homeostasis, and it has been suggested that ANGPTL4 antagonists may be used in the treatment of T2D. (Gusarova et al., 2018). The glucose and insulin homeostasis controlled by angiopoietin-like proteins-4 (ANGPTL4) is partially uncoupled from lipid partitioning (Janssen et al., 2018); nevertheless, knowledge on the processes controlling ANGPTL4 effects on human glucose regulation is sparse. Angiopoietin-like proteins- 4 is produced and released by a variety of tissues and organs, primarily via AT and the liver (Mandard et al., 2004) While ANGPTL3 is produced mostly with the help of hepatocytes found inside the liver (Arca et al., 2013), (Barchetta et al., 2020). Angiopoietin-like proteins-4 are a group of proteins that are similar to angiopoietin. It controls plasma triglycerides and inhibits lipoprotein lipase (LPL), an enzyme that regulates fat deposition by facilitating the conversion of lipoproteins to fat tissue and regulating fat cellular length and growth (Dijk W et al., 2018) (W. van Dijk and colleagues, 2014).

\section{Regulation of ANGPTL4 Expression and Location in Lipid Metabolism}

Fasting increases ANGPTL4 expression in white adipose tissue via the action of many molecules, including PPARs, HIF-1, and GR. Protein promotes TG breakdown by inhibiting LPL. PPARiso develops in the liver, and GR promotes ANGPTL4 expression. ANGPTL4 works in part on hepatic LP and, in part, is released into the circulation, where it appears on LPL in peripheral tissues. FAs activate PPAR in skeletal muscle, the coronary heart, and macrophages, resulting in the production of ANGPTL4. FAs also promote ANGPTL4 expression in the gut through one of the PPARs. Enterocytes generate ANGPTL4, which is released into the lumen and inhibits pancreatic LP (F. Mattijssen et al., 2014).

\section{ANGPTL4 Gene: \\ Definition:}

This gene produces a secreted glycosylated protein with a fibrinogen region at the $\mathrm{C}$-terminus. The encoded protein is a serum hormone that controls glucose homeostasis, lipid metabolism, and insulin sensitivity. It is produced by peroxisome proliferation activators. This protein may also help vascular endothelial cells survive apoptosis, which might prevent metastasis by reducing vascular development and tumor cellular invasion. In this research, single nucleotide polymorphisms (rs2010871) of angiopoietin-like protein 4 were utilized in Table 1. 


\section{Al-Nahrain Journal of Science}

ANJS, Vol.24 (4), December, 2021, pp. 7-14

Table 1. The properties of (rs2010871) in this table.

\begin{tabular}{||c|c|c||}
\hline \hline 1 & Organism & Homo sapiens \\
\hline 2 & Position & omo sapiens Position chr19:8363686 (GRCh38.p13) \\
\hline 3 & Alleles $>\mathrm{T}$ \\
\hline 4 & Variation Type & NV Single Nucleotide Variation \\
\hline & & $\mathrm{T}=0.480543(127195 / 264690$, TOPMED) \\
5 & Frequency & $\mathrm{T}=0.491711(68754 / 139826$, GnomAD) \\
& & $\mathrm{C}=0.48888(9235 / 18890$, ALFA) $(+12$ more $)$ \\
\hline 6 & Clinical Significance & Not Reported in ClinVar \\
\hline 7 & Gene Consequence & ANGPTL4: 2KB Upstream Variant \\
\hline
\end{tabular}

\section{Function of ANGPTL4 Gene:}

Has a function in the clearance of triglycerides from the serum and lipid metabolism by mediating the inactivation of the lipoprotein lipase LPL. It's also possible that it regulates glucose homeostasis and insulin sensitivity (Cohen et al., 2009) (Lei et al., 2011) (Kristensen et al., 2018) (Cazes et al., 2006). Endothelial cell growth, migration, and tubule formation are inhibited, and vascular leakage is reduced (Ito Y et al., 2003) (Cazes et al., 2006). Inhibits endothelial cell adherence to the extracellular matrix (ECM), as well as actin cytoskeleton rearrangement, actin strain fiber formation, and focal adhesions in endothelial cells adhering to ANGPTL4-containing ECM in vitro (Cazes A et al., 2006). It may have an impact on tumorrelated angiogenesis depending on the circumstances.

\section{Methods Subjects}

From 2020 to 2021, participants in this case-control research were chosen from visits to a specialist specializing in endocrinology and diabetes in Baghdad. A total of 75 people took part in the study: 25 people with T2DM and 50 people who did not have diabetes mellitus. Type 2 diabetes diagnosis must have been made by a physician at least one year earlier, according to ADA guidelines. Following the participants' verbal consent, data was gathered from them through a questionnaire designed especially for the study. Every participant's body weight and height were measured using a Seca-USA scale and a wall-mounted stadiometer, and they were both recorded to the closest $0.5 \mathrm{~kg}$ and 0.5 $\mathrm{cm}$, respectively. By multiplying the body weight in kilograms by the squared height in meters, the BMI was determined. Control group participants' blood glucose levels were normal (no diabetes history). Patients and controls were excluded if they had type 1 diabetes, were pregnant, were on hormone replacement therapy, had cancer, were severely ill with or recovering from an acute or chronic infectious disease, had systemic illnesses (such as heart failure, lung disease, liver and kidney), had thyroid, or had adrenal issues. All operations were carried out at AlImmamain Al-Kahdymian teaching hospital, ASCO learning center, and Al-Janaen Lab; the research protocol was authorized by Al-Nahrain University College of Medicine in Baghdad, Iraq.
Hormone analyses and Biochemical parameters:

Subjects were fasted overnight and then gave blood samples $(10 \mathrm{ml})$ from a forearm vein in the morning for hormone and biochemical testing. The sample was centrifuged at 4500 $\mathrm{rpm}$ for 5 minutes to separate serum; this serum was used to estimate FSG, HbAlc, and lipid profile via an automated immunoassay analyzer (Cobas c111, Roche Diagnostics GmbH, D-68298 Mannheim, Germany). The remaining serum was immediately placed in a new tube and centrifuged at $450 \mathrm{rpm}$ to collect serum. An automated immunoassay analyzer (Cobas c111, Roche Diagnostics GmbH, D-68298 Mannheim, Germany) was used to perform direct measurement of glycated hemoglobin (HbA1C) and analysis of the ANGPTL4 gene.

\section{Serum ANGPTL4 assay:}

An Absorbance Microplate Reader (ELx800TM, Operator's Manual, Biokit, Wefen com. Spain) and a commercial enzyme -linked immune sorbent assay (ELISA) kit (Biovendor- Laboratorin medicine a.s., Karasek 1767/1, 62100 Brno, Czech Republic) was used to measure the level of fasting blood ANGPTL4. The standard curve has a range of $0.94-60 \mathrm{ng} / \mathrm{ml}$ Inter-assay and intra-assay coefficients of variation were $5 \%$ and $8 \%$, respectively.

\section{Genotyping:}

35 samples were collected (10) of controls, (25) of diabetic patients, and then DNA samples were extracted and then concentration measurements were taken. The results of the DNA concentrations were (25-50) $\mathrm{ng} / \mu \mathrm{l}$. Genomic DNA was extracted from a blood sample using the Relia Prep ${ }^{\mathrm{TM}}$ Blood gDNA Miniprep System (Agarose, Ethidium Bromide Solution $(10 \mathrm{mg} / \mathrm{ml})$, GoTag Green Master Mix, Nuclease Free Water, TAE 40X, Quantifluor dsDNA System) kit and company (Promega, USA). Primer preparation primers were provided by Macrogen Company in lyophilized form. As a stock solution, lyophilized primers were dissolved in nuclease-free water to a final concentration of $100 \mathrm{pmol} / \mu \mathrm{l}$. To produce a workable primer solution of $10 \mathrm{pmol} / \mu \mathrm{l}, 10 \mu \mathrm{l}$ of primer stock solution (stored at freezer $-20 \mathrm{C}$ ) was mixed with $90 \mu \mathrm{l}$ of nuclease free water. (25-50) ng/ $\mu \mathrm{l}$ DNA concentration range. 


\section{Al-Nahrain Journal of Science}

ANJS, Vol.24 (4), December, 2021, pp. 7-14

\section{Statistical Analysis}

Were performed using Graph Pad Prism Version 8 (Graph Pad Software Inc. La Jolla, CA). One-way Anova (Tukey's post hoc analysis) was used to determine whether group variance was significant or not. Pearson coefficient (r) was employed to assess correlations. Alleles and genotypes of gene SNPs were presented as numbers and \% frequencies. Harding-Weinberg equilibrium analysis of genotype frequencies was performed using the Chi-square test. Data were expressed as mean $\pm \mathrm{SD}$ and statistical differences were defined as $\mathrm{p} \leq 0.05$ or $\mathrm{p} \leq 0.01$.

Sensitivity: assess the test's ability to identify a positive illness.

Specificity: Estimate the probability of properly ruling out patients who do not have a disease.

Receiver operator characteristic curve (ROC): is a visual representation of the connection between sensitivity and specificity that aids in the selection of the appropriate model by establishing the optimum diagnostic test threshold. The goal of ROC was to find a cutoff value that accurately predicted specific prognostic criteria.

\section{Results}

There were 75 participants in the study: 25 patients with T2DM (13 men; 12 females) ranging in age from 30 to 50 years, and 50 healthy individuals ( 25 males; 25 females) ranging in age from 30 to 50 years. T2DM patients had a mean BMI of $28 \pm 2.95$ while controls had a mean BMI of 23.4 \pm 1.5 .

T2DM and non-diabetic groups' biochemical indicators were compared:

In patients with T2DM, the fasting serum Angiopoietin-like protein 4 level was substantially $(\mathrm{p}=0.0001)$ greater than in the control group, as shown in Table 2 and Figure 1 $(135.1 \pm 6.70) \mathrm{ng} / \mathrm{ml}$ and $(62.35 \pm 6.4) \mathrm{ng} / \mathrm{ml}$, respectively. When compared to the control group, patients with T2DM had substantially higher FSG, lipid profile, and HbA1C values. At the same time, the estimated BMI in the T2DM group was greater. rs2010871 polymorphism genotypes (CC, CT, TT) There was a significant difference in the frequency of the control group (P 0.0477), but not in the level of (diabetics, newly diagnosed type 2 diabetic before treatment) p-value $(0.7066,0.5555)$.

Table 2. Fasting blood levels of Angiopoietin- like protein 4, FBS, lipid profile, estimated BMI, and HbA1C were compared across the research groups based on laboratory examinations.

\begin{tabular}{||c|c|c|c||}
\hline Characteristic & $\begin{array}{c}\text { Control group (1) } \\
\text { N 50 } \\
\text { mean } \pm \text { SD }\end{array}$ & $\begin{array}{c}\text { Type 2 DM group (2) } \\
\text { N 25 } \\
\text { mean } \pm \text { SD }\end{array}$ & p-value \\
\hline \hline Age (years) & $39.51 \pm 8.60$ & $43.01 \pm 6.85$ & $0.1746 \phi(\mathrm{NS})$ \\
\hline BMI $\left(\mathrm{kg} / \mathrm{m}^{2}\right)$ & $23.4 \pm 1.5$ & $28 \pm 2.95$ & $<0.0001 \phi(\mathrm{HS})$ \\
\hline FBS (mg/dl) & $95.04 \pm 6.15$ & $167.4 \pm 15.00$ & $<0.0001 \phi(\mathrm{HS})$ \\
\hline HbA1c (\%) & $5.42 \pm 0.39$ & $9.05 \pm 1.21$ & $<0.0001 \phi(\mathrm{HS})$ \\
\hline Triglycerides (mg/dl) & $123.73 \pm 44.8$ & $178.56 \pm 55.2$ & $<0.0001 \phi(\mathrm{HS})$ \\
\hline HDL $(\mathrm{mg} / \mathrm{dl})$ & $43.41 \pm 3.58$ & $34.32 \pm 4.81$ & $<0.0001 \phi(\mathrm{HS})$ \\
\hline LDL $(\mathrm{mg} / \mathrm{dl})$ & $86.54 \pm 32.9$ & $126 \pm 35.79$ & $<0.0001 \phi(\mathrm{HS})$ \\
\hline VLDL $(\mathrm{mg} / \mathrm{dl})$ & $24.37 \pm 5.76$ & $32.90 \pm 7.42$ & $<0.0001 \phi(\mathrm{HS})$ \\
\hline Angiopoietin like protein 4 (ng./ml) & $62.35 \pm 6.4$ & $135.1 \pm 6.70$ & $<0.0001 \phi(\mathrm{HS})$ \\
\hline
\end{tabular}

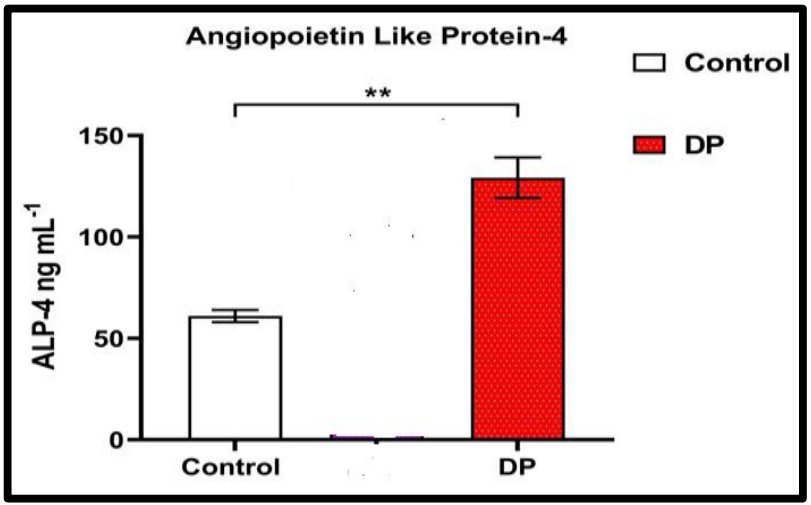

Figure 1. Comparison between serum Angiopoietin-like protein 4 levels in control and T2DM groups. $* * \mathrm{p}<0.01$ highly significant.

NS: no significant.

DP: diabetic patients. 


\section{Al-Nahrain Journal of Science}

ANJS, Vol.24 (4), December, 2021, pp. 7-14

The diagnostic utility of angiopoitein like protein 4 in diabetes mellitus:

The existence of a cutoff value that may predict a diabetes diagnosis with a high degree of accuracy. according to the authors of the current study, was suggested by the highly significant difference in the level of angiopoietin-like protein 4 in diabetic patients when compared to the control group. As a result, a receiver operator characteristic (ROC) curve analysis was carried out, and the results were as follows, shown in Figure 2 and Table 3. The cut off value was > 67.9, with a 100 percent accuracy, a 100 percent sensitivity, and a 100 percent specificity, as indicated in Table 3.

Table 3. Characteristics of ROC analysis in T2DM.

\begin{tabular}{|c|c|c|c|c|c|c|c|}
\hline Markers & Cut-Off & AUC & 95\% CI & accuracy & p-value & Se. & Sp. \\
\hline \hline $\begin{array}{c}\text { Angiopoietin } \\
\text { like protein-4 }(\mathrm{ng} / \mathrm{ml})\end{array}$ & $>67.9$ & 1.000 & 0.952 to 1.00 & $100 \%$ & $<0.0001$ & 100 & 100 \\
\hline
\end{tabular}

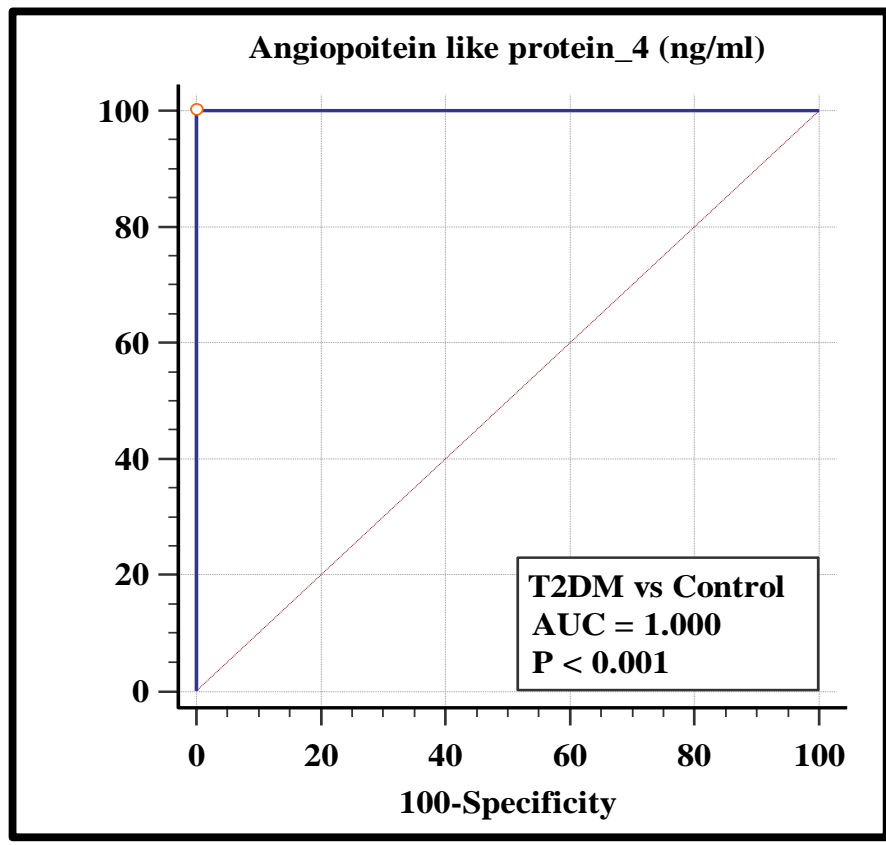

Figure 2. The ROC curve depicts the sensitivity and specificity of the levels of Angiopoietin-like protein 4 during T2DM. AUC stands for Area Under the Curve.

Genotype:

Rs2010871 polymorphism

Table 4. rs2010871 polymorphism in diabetic patients.

\begin{tabular}{|c|c|c|c|c|c|}
\hline \multicolumn{6}{|c|}{ Rs2010871 polymorphism Frequency (\%) } \\
\hline Genotype & Control $(n=10)$ & $\mathrm{DP}(\mathrm{N}=\mathbf{2 5})$ & $p$-value & Odds Ratio & $95 \% \mathrm{Cl}$ \\
\hline $\mathrm{CC}$ & $6(60 \%)$ & $5(20 \%)$ & - & 1.0 & \\
\hline $\mathrm{CT}$ & $1(10 \%)$ & $10(40 \%)$ & $0.0402 *$ & 12.0 & 1.1177 to 128.8417 \\
\hline TT & $3(3 \%)$ & $10(40 \%)$ & $0.1212 \mathrm{NS}$ & 4.0 & 0.6930 to 23.0894 \\
\hline Chi-squared & 6.0874 & $0.6944 \mathrm{NS}$ & & & \\
\hline$P$ value & $0.0477 *$ & 0.7066 & & & \\
\hline \multicolumn{6}{|c|}{ Allele frequency $(\%)$} \\
\hline Allele & Control $(n=10)$ & DP $(n=25)$ & $p$-value & Odds Ratio & $95 \% \mathrm{Cl}$ \\
\hline $\mathrm{C}$ & $0.65(7)$ & $0.4(10)$ & \multirow{2}{*}{0.0691} & \multirow{2}{*}{2.786} & \multirow{2}{*}{0.9816 to 7.614} \\
\hline $\mathrm{T}$ & $0.35(3)$ & $0.6(15)$ & & & \\
\hline
\end{tabular}




\section{Al-Nahrain Journal of Science}

ANJS, Vol.24 (4), December, 2021, pp. 7-14

(CC, CT, TT) genotypes of the rs2010871 polymorphism

There was a significant difference in frequency of the control group ( $p<0.0477)$; however, there was no significant difference in its level of (diabetics, newly diagnosed type 2 diabetic before treatment) p-value $(0.7066,0.5555)$ respectively, as shown in Table 4.

Table 5. rs2010871 polymorphism with parameters and biochemical marker in control and patients.

\begin{tabular}{|c|c|c|c|c|}
\hline Characteristic & $\begin{array}{c}\text { Rs } \\
2010871\end{array}$ & $\begin{array}{c}\text { Control group (1) } \\
\mathrm{n}=\mathbf{1 0} \\
\mathrm{mean} \pm \mathrm{SD} \\
\end{array}$ & $\begin{array}{c}\text { Type } 2 \text { DM group (2) } \\
n=25 \\
\text { mean } \pm \text { SD } \\
\end{array}$ & p-value \\
\hline \multirow{3}{*}{ Age(years) } & $\mathrm{CC}$ & $39.67 \pm 5.92$ & $41.40 \pm 5.03$ & $0.8642(\mathrm{NS})$ \\
\hline & $\mathrm{CT}$ & 44.00 & $41.80 \pm 4.24$ & $0.9245(\mathrm{NS})$ \\
\hline & $\mathrm{TT}$ & $43.33 \pm 10.69$ & $41.00 \pm 4.24$ & $0.7999(\mathrm{NS})$ \\
\hline \multirow{3}{*}{ BMI $\left(\mathrm{kg} / \mathrm{m}^{2}\right)$} & $\mathrm{CC}$ & $23.22 \pm 0.95$ & $28.20 \pm 1.62$ & $0.0002(\mathrm{HS})$ \\
\hline & $\mathrm{CT}$ & 24.50 & $28.41 \pm 0.85$ & $0.1256(\mathrm{NS})$ \\
\hline & $\mathrm{TT}$ & $23.07 \pm 1.39$ & $28.44 \pm 1.74$ & $0.0002(\mathrm{HS})$ \\
\hline \multirow{3}{*}{ FBS (mg/dl) } & $\mathrm{CC}$ & $97.04 \pm 3.25$ & $140.52 \pm 6.13$ & $<0.0001(\mathrm{HS})$ \\
\hline & $\mathrm{CT}$ & 98.40 & $133.15 \pm 16.65$ & $0.0280(\mathrm{~S})$ \\
\hline & $\mathrm{TT}$ & $97.59 \pm 3.49$ & $136.85 \pm 19.00$ & $<0.0001(\mathrm{HS})$ \\
\hline \multirow{3}{*}{ HbA1c $(\%)$} & $\mathrm{CC}$ & $5.38 \pm 0.25$ & $9.82 \pm 1.43$ & $<0.0001(\mathrm{HS})$ \\
\hline & $\mathrm{CT}$ & $5.40 \pm$ & $9.63 \pm 1.15$ & $0.0004(\mathrm{HS})$ \\
\hline & TT & $5.25 \pm 0.34$ & $9.36 \pm 1.34$ & $<0.0001(\mathrm{HS})$ \\
\hline
\end{tabular}

Table 6. rs2010871 polymorphism with lipid profile in control and patients.

\begin{tabular}{|c|c|c|c|c|}
\hline $\begin{array}{c}\text { CHARACTERI } \\
\text { STIC }\end{array}$ & $\begin{array}{c}\text { Rs } \\
2010871\end{array}$ & $\begin{array}{c}\text { Control group (1) } \\
\mathrm{n}=\mathbf{1 0} \\
\text { mean } \pm \mathrm{SD} \\
\end{array}$ & $\begin{array}{c}\text { Type } 2 \text { DM group (2) } \\
\mathrm{n}=\mathbf{2 5} \\
\text { mean } \pm \text { SD } \\
\end{array}$ & p-value \\
\hline \multirow{3}{*}{$\begin{array}{l}\text { Cholesterol } \\
\text { (mg\dl) }\end{array}$} & $\mathrm{CC}$ & $\begin{array}{c}165.69 \pm 32.6 \\
32.69 \\
\end{array}$ & $\begin{array}{c}181.80 \pm 28.49 \\
28.49 \\
\end{array}$ & 0.6306 (NS) \\
\hline & $\mathrm{CT}$ & 130.00 & $191.10 \pm 18.24$ & $0.1211(\mathrm{NS})$ \\
\hline & $\mathrm{TT}$ & $156.67 \pm 12.0$ & $192.90 \pm 28.07$ & $0.1502(\mathrm{NS})$ \\
\hline \multirow{3}{*}{$\begin{array}{l}\text { Triglyceride } \\
\text { (mgldl) }\end{array}$} & $\mathrm{CC}$ & $117.11 \pm 35.3$ & $198.60 \pm 16.50$ & 0.0039 (HS) \\
\hline & $\mathrm{CT}$ & 150.10 & $201.40 \pm 35.49$ & $0.4336(\mathrm{NS})$ \\
\hline & $\mathrm{TT}$ & $126.37 \pm 42.2$ & $197.90 \pm 30.88$ & $0.022(\mathrm{~S})$ \\
\hline \multirow{3}{*}{$\begin{array}{c}\text { HDL } \\
\text { (mgldl) }\end{array}$} & $\mathrm{CC}$ & $44.18 \pm 4.29$ & $35.30 \pm 4.60$ & $0.0131(\mathrm{HS})$ \\
\hline & $\mathrm{CT}$ & 42.10 & $34.28 \pm 5.64$ & $0.2942(\mathrm{NS})$ \\
\hline & TT & $41.65 \pm 3.40$ & $33.20 \pm 4.36$ & $0.0330(\mathrm{~S})$ \\
\hline \multirow{3}{*}{$\begin{array}{l}\text { LDL } \\
(\mathrm{mg} \backslash \mathrm{dl})\end{array}$} & $\mathrm{CC}$ & $94.20 \pm 21.46$ & $141.20 \pm 25.67$ & $0.0056(\mathrm{HS})$ \\
\hline & $\mathrm{CT}$ & 109.10 & $138.18 \pm 24.60$ & $0.4725(\mathrm{NS})$ \\
\hline & TT & $66.33 \pm 13.39$ & $136.52 \pm 23.97$ & $0.0001(\mathrm{HS})$ \\
\hline \multirow{3}{*}{$\begin{array}{l}\text { VLDL } \\
(\mathrm{mg} \backslash \mathrm{dl})\end{array}$} & $\mathrm{CC}$ & $26.52 \pm 6.80$ & $31.80 \pm 7.43$ & $0.5144(\mathrm{NS})$ \\
\hline & $\mathrm{CT}$ & 30.20 & $36.41 \pm 8.04$ & 0.7339 (NS) \\
\hline & TT & $20.32 \pm 4.87$ & $31.35 \pm 7.51$ & $0.0965(\mathrm{NS})$ \\
\hline
\end{tabular}




\section{Al-Nahrain Journal of Science}

ANJS, Vol.24 (4), December, 2021, pp. 7-14

Table 7. rs2010871 polymorphism with Angiopoietin like protein- 4 in control and patients.

\begin{tabular}{||c|c|c|c|c||}
\hline \multirow{2}{*}{ Characteristic } & $\begin{array}{c}\text { Rs } \\
\mathbf{2 0 1 0 8 7 1}\end{array}$ & $\begin{array}{c}\text { Control group (1) } \\
\mathbf{n = 1 0} \\
\text { mean } \pm \text { SD }\end{array}$ & $\begin{array}{c}\text { Type 2 DM group (2) } \\
\mathbf{n = 2 5} \\
\text { mean } \pm \text { SD }\end{array}$ & p-value \\
\hline \hline $\begin{array}{c}\text { Angiopoietin like } \\
\text { protein 4 } \\
(\mathrm{ng} / \mathrm{ml})\end{array}$ & $\mathrm{CC}$ & $63.05 \pm 3.99$ & $131.62 \pm 9.37$ & $<0.0001(\mathrm{HS})$ \\
\cline { 2 - 5 } & $\mathrm{CT}$ & 59.40 & $132.52 \pm 4.28$ & $<0.0001(\mathrm{HS})$ \\
\cline { 2 - 5 } & $\mathrm{TT}$ & $59.63 \pm 2.46$ & $126.97 \pm 11.9$ & $<0.0001(\mathrm{HS})$ \\
\hline
\end{tabular}

\section{Discussion}

Davies BSJ et al., 2018) angiopoietin-like protein 4 has lately gained interest as a possible pharmaceutical therapy for insulin resistance and Type 2 diabetes (Janssen AWF et al., 2018). ANGPTL4 is a protein that is produced in response to fasting and was previously known as a fastinginduced adipose factor (Mandard S et al., 2007). It affects fat cell size and growth by regulating plasma triglycerides and decreasing the activity of the lipoprotein lipase (LPL) enzyme, which catalyzes the transfer of lipoproteins into fat tissue and controls fat accumulation (Dijk et al., 2018). (Dijk et al., 2014).

There was A highly significant difference in means angiopoietin-like protein 4level among study groups ( $\mathrm{p}<$ 0.0001 ) in such a way that diabetics' patients had the highest level followed by the control subject. Angiopoietin like proteins 4 was higher in type 2 diabetes mellitus group compared with the control group this agreement with the studies (Tjeerdema $\mathrm{N}$ et al., 2014) (Xu A et al., 2005).

The ROC curve analysis, on the other hand, revealed that Angiopoietin like proteins 4 is a biomarker for T2DM, with an AUC of 0.001 and a $p<0.001$. In this study we found the Plasma Angiopoietin like protein 4 was negatively correlated to LDL-C and HDL-C, but positively associated with serum triglycerides it is an agreement with this study(Mehta $\mathrm{N}$ et al., 2014),over expression of plasma angiopoietin-like protein 4may play a crucial role in lipid metabolism (Georgiadi A et al., 2013).plasma angiopoietinlike protein 4 was negatively correlated to body mass index (BMI).plasma angiopoietin-like protein 4 was negatively correlated to fasting blood glucose level but positively correlated to $\mathrm{HbA1c}$ it is agreement with this study (Cinkajzlová et al.,2018) (Barja-Fernandez S et al., 2018).Significant low of gene in type 2 diabetes groups compared with a control group and it is as the biomarker in diagnose of the type 2 diabetic patients. In this study, we tried to investigate the role of gene The Rs2010871 in type 2 diabetes mellitus we found a significant decrease of gene The Rs2010871 diabetic patients when compared to controls .The Rs 2010871 gene is no significant with fasting glucose, HbA1c, lipid profile just LDL-C and BMI, but higher significance with plasma Angiopoietin like protein 4 $\mathrm{p}$ - value $(\mathrm{p}<0.0001)$.

\section{Conclusion}

The significant high concentration of ANGPTL4in type2 patients and good as a biomarker to diagnose the type 2 diabetic patient and have very good specific and sensitive cut off value as bio-marker. In summary, our findings show a link between the rs2010871 genetic polymorphism in the ANGPTL4 gene and the prevalence of type 2 diabetes and lipid profile.

\section{References}

[1] Arca M.; Minicocci I.; Maranghi M.; "The angiopoietin-like protein 3: A hepatokine with expanding role in metabolism". Curr Opin Lipidol. 24(4), 313-20, 2013.

[2] Association A. D.; "Classification and Diagnosis of Diabetes: Standards of Medical Care in Diabetes2020". Diabetes Care.; 43(Supplement 1), S14-S31, 2020.

[3] Association A. D.; "Classification and diagnosis of diabetes: standards of medical care in diabetes2018". Diabetes care.; 41(Supplement 1), S13-S27, 2018.

[4] Bailetti D.; Bertoccini L.; Mancina, R. M.; Barchetta I.; Capoccia D.; Cossu E.; Pujia A.; Lenzi A.; Leonetti F. and Cavallo M. G.; "ANGPTL4 gene E40K variation protects against obesity-associated dyslipidemia in participants with obesity". Obes Sci Pract. 5(1), 83-90, 2019.

[5] Barchetta I.; Cimini F. A.; Chiappetta C.; Bertoccini L.; Ceccarelli V.; Capoccia D.; Gaggini M.; Di Cristofano, C.; Rocca C. D.; Silecchia G.; "Relationship between hepatic and systemic angiopoietin-like 3, hepatic Vitamin D receptor expression and NAFLD in obesity". Liver Int. 40(9), 2139-2147, 2020.

[6] Davies B. S.; "Can targeting ANGPTL proteins improve glucose tolerance ?". Diabetologia. 61(6), 1277-1281, 2018.

[7] Dijk W. and Kersten S.; "Regulation of lipid metabolism by angiopoietin-like proteins". Current Opinion in Lipidology. 27(3), 249-256, 2016.

[8] Dijk W.; Ruppert P. M.; Oost L. J. and Kersten S.; "Angiopoietin-like 4 promotes the intracellular cleavage of lipoprotein lipase by PCSK3/furin in adipocytes". J Biol Chem. 7; 293(36), 14134-14145, 2018.

[9] Dijk W.; Schutte S.; Aarts E. O.; Janssen I. M.; Afman L. and Kersten S.; "Regulation of angiopoietin-like 4 and lipoprotein lipase in human 


\section{Al-Nahrain Journal of Science}

ANJS, Vol.24 (4), December, 2021, pp. 7-14

adipose tissue". J. Clin Lipidol. 12(3), 773-783, 2018.

[10] Gusarova V.; O’Dushlaine C.; Teslovich T. M.; Benotti P. N.; Mirshahi T.; Gottesman O.; Van Hout C. V.; Murray M. F.; Mahajan A. and Nielsen J. B.; "Genetic inactivation of ANGPTL4 improves glucose homeostasis and is associated with reduced risk of diabetes". Nature Communications. 9(2252), 2018.

[11] International Diabetes Federation. IDF DIABETES ATLAS. $8^{\text {th }}$ Edition, 2017. Available at: https://www.idf.org/elibrary/epidemiologyresearch/diabetes-atlas.html. Accessed at: $5^{\text {th }}$ Nov 2019.

[12] Janssen A.W.F.; Katiraei S.; Bartosinska B.; "Loss of angiopoietin-like 4 (ANGPTL4) in mice with diet-induced obesity uncouples visceral obesity from glucose intolerance partly via the gut microbiota". Diabetologia. 61(6), 1447-1458, 2018.

[13] Kersten S.; "New insights into angiopoietin-like proteins in lipid metabolism and cardiovascular disease risk". Curr Opin Lipidol. 30(3), 205-211, 2019.

[14] Mandard S.; Zandbergen F.; Escher P.; Patsouris, D.; Koenig W.; Bakker A.; Veenman F.; Wahli W.; Kersten S. and Tan N. S.; "The Direct Peroxisome Proliferator-activated Receptor Target Fastinginduced Adipose Factor (FIAF/PGAR/ANGPTL4) Is Present in Blood Plasma as a Truncated Protein That Is Increased by Fenofibrate Treatment". J Biol Chem. 279 (33), 34411-20, 2004.

[15] Quagliarini F.; Wang Y. and Kozlitina J.; "A typical angiopoietin-like protein that regulates ANGPTL3". Proc Natl Acad Sci U S A. 27; 109(48), 19751-6, 2012.

[16] Romeo S.; Yin W.; Kozlitina J.; Pennacchio L. A.; Boerwinkle E.; Hobbs H. H. and Cohen J. C.; "Rare loss-of-function mutations in ANGPTL family members contribute to plasma triglyceride levels in humans". J. Clin. Invest. 119 (1):70-9, 2009.

[17] Ruscica M.; Zimetti F.; Adorni M.P.; Sirtori C.R.; Lupo M.G. and Ferri N.; "Pharmacological aspects of ANGPTL3 and ANGPTL4 inhibitors: New therapeutic approaches for the treatment of atherogenic dyslipidemia". Pharmacol Res. 153, 10465, 2020.

[18] Sonnenburg W. K.; Yu D.; Lee E.-C.; Xiong W.; Gololobov G.; Key B.; Gay J.; Wilganowski N.; $\mathrm{Hu}$ Y. and Zhao S.; "GPIHBP1 stabilizes lipoprotein lipase and prevents its inhibition by angiopoietin-like 3 and angiopoietin-like 4". J. Lipid Res. 50(12), 2421-2429, 2009.

[19] Wang Y.; Li, L. -M.; We, L.; Y, W. -W.; Men, X. -Y.; Che F.; Xia Q.; Chen J. -Y. and Zhou Y.; "Angiopoietin-like protein 4 improves glucose tolerance and insulin resistance but induces liver steatosis in high-fat-diet mice" Mol Med Rep. 14(4), 3293-300, 2016.

[20] Xu A.; Lam M. C.; Chan K. W.; Wang Y.; Zhang J.; Hoo R. L. C.; Xu J. Y.; Chen B.; Chow W. -S. and Tso, A. W. K.; "Angiopoietin-like protein 4 decreases blood glucose and improves glucose tolerance but induces hyperlipidemia and hepatic steatosis in mice". Proc Natl Acad Sci USA. 26; 102(17), 6086-91, 2005. 